\title{
EPIDEMIOLOGICAL STUDIES AND MOLECULAR CHARACTERIZATION OF CLOSTRIDIUM PERFRINGENS IN SMALL RUMENIANT AT EI-BEHERA GOVERNORATE, EGYPT
}

\author{
OMAR, A.A. ${ }^{1}$; BAKER, N.M. ${ }^{2}$; BKHEET, A.A. ${ }^{1}$; KHDER, A.M. ${ }^{3}$ and NASR, M.Y. ${ }^{2}$ \\ ${ }^{1}$ Animal Health Research Institute, Damanhur. \\ 2 Animal Med. Dept., Fac. of Vet. Medicine, Damanhur University. \\ ${ }^{3}$ Animal Med. Dept., Fac. of Vet. Medicine, Alexandria University.
}

Received: 31 December 2017; Accepted: 21 January 2018

\begin{abstract}
Epidemiological factors associated with clostridium infection among sheep and goats. Through the collection of samples from suspected cases of sheep and goat, anaerobic isolation and identification of $C$. perfringens by using classical methods and application of multiplex PCR for molecular characterization of isolates. A total of 104 samples were collected from intestine, liver, kidney and spleen from sheep and goat either those showing signs of enterotoxaemia or suddenly dead from different farms and small holders at El- Behera Governorate for anaerobic bacteriological examination. Our study concluded that, the $C$. perfringens causes high mortality in sheep and goat as a result secretion of Alpha, Beta and Epislon toxins. Molecular characterization of $C$. perfringens by Multiplex PCR characterize $C$. perfringenstype " $A$ " (alpha toxin) which gave a characteristic band at $402 \mathrm{bp}$.
\end{abstract}

Key words: C.perfringens, Enterotoxaemia, Epidemiology, Multiplex PCR, Sheep, Goats.

\section{INTRODUCTION}

Heterogeneous group of environmental bacteria can be found as pathogens in animals (Liu, 2011) one from this bacteria is the $C$. perfringens is a Gram-positive spore-forming anaerobic bacterium present in the intestinal flora of animals as well as in soil and water, where its presence might be indicative of fecal contamination (Jemal et al.,2016).

C. perfringens is classified into 5 toxin types (A, B, $\mathrm{C}, \mathrm{D}$, and $\mathrm{E}$ ) according to the production of 4 toxins, namely alpha (CPA), beta (CPB), epsilon (ETX) and iota (ITX). Several other toxins (e.g. enterotoxin (CPE), beta 2 (CPB2) and perfringolysin O (PFO) can also be produced by some strains of all types of $C$. perfringens, but they are not currently used in the classification of this microorganism (Tabaran, 2017).

Alpha toxin is commonly produced by all five types and is a phospholipase $\mathrm{C}$ that can hydrolyze lecithin into phosphorylcholine and diglyceride and is believed to be a major factor responsible for the organism's tissue pathology (Rodriguez et al., 2016).

C. perfringens is an anaerobic bacterium that produces several toxins. Of these, the alpha, beta, and epsilon toxins are responsible for causing the most

Corresponding author: Dr. OMAR A.A.

E-mail address: ahmadbkheet@yahoo.com

Present address: Animal Health Research Institute, Damanhur. severe $C$. perfringens-related diseases in farm animals (Moreira et al., 2016).

The Multiplex PCR is the best method for identification of $C$. perfringens with determination of its molecular structure (Ashgan et al., 2013) used a simple mPCR procedure to identify four toxitypes of C. perfringens collected from different origins by using genes of alpha, beta, epsilon and iota toxins. Also, Eman et al. (2013) performed PCR for molecular typing of $C$. perfringens was by using three sets of primers specific for toxin -producing genes of C. perfringens alpha (900bp), beta (236bp) and epsilon (541bp). Dean et al. (2011) concluded that, the PCR results is more accurate when used tissue samples than colony samples.

This study was carried to showepidemiological factors associated with clostridium infection and molecular characterization of $C$. perfringens in sheep.

\section{MATERIALS AND METHODS}

A total of 104 samples from intestine, liver, kidney and spleen were collected from sheep and goat either those showing signs of enterotoxaemia or recent suddenly dead. All samples were obtained from different farms and small holders at El-Behera Governorate. The samples were labeled and placed in sterile plastic bags and transported in ice box as soon as possible for anaerobic bacteriological examination. 
Table 1: Type and number of examined samples.

\begin{tabular}{ccc}
\hline Animal species & $\begin{array}{c}\text { Number of examined } \\
\text { samples }\end{array}$ & Type of samples $\backslash$ organs \\
\hline Sheep & 83 & Intestine, liver, kidney and spleen \\
\hline Goat & 21 & Intestine, liver , kidney and spleen \\
\hline Total & & 104 \\
\hline
\end{tabular}

2. Enrichment and isolation of $\mathrm{C}$. perfringens according to (Smith and Holdman, 1968). The samples were inoculated into tubes of freshly prepared and previously boiled cooked meat medium.

3. Identification of isolated bacteria according to (Koneman et al., 1992), all suspected isolates that obtained were identified as follows:

a. Colonial appearance according to (Vaikosen and Muller, 2001).

b. Microscopicalappearance c. Biochemical identification:

Suspected purified isolates were identified according to the schemes of (Koneman et al., 1992) depending on the following tests catalase test, gelatin hydrolysis test, fermentation of sugars (glucose, lactose, sucrose, galactose, manitol, maltose xylose and mannose), indole test, $\mathrm{H}_{2} \mathrm{~S}$ production and lecithinase activity.

d. Extraction of DNA according to QIAamp DNA mini kit instructions.

e. Preparation of multiplex PCR Master mix for Alpha, beta, epsilon, Iota: (Table2)

\begin{tabular}{cc}
\hline Component & Volume/reaction \\
\hline Emerald Amp GT PCR mastermix (2x premix) & $\mathbf{2 5} \boldsymbol{\mu l}$ \\
\hline PCR grade water & $\mathbf{1 1} \boldsymbol{\mu l}$ \\
\hline Forward primer $(20 \mathrm{pmol})$ & $\mathbf{1} \boldsymbol{\mu l}$ each \\
\hline Reverse primer $(20 \mathrm{pmol})$ & $\mathbf{1} \boldsymbol{\mu l}$ each \\
\hline Template DNA & $\mathbf{8} \boldsymbol{\mu l}$ \\
\hline Total & $\mathbf{5 0} \boldsymbol{\mu l}$ \\
\hline
\end{tabular}

Oligonucleotide primers used for conventional:

Source: Midland Certified Reagent Company_oilgos (USA): Table3

\begin{tabular}{|c|c|c|c|c|}
\hline Toxin & Primer & Sequence & $\begin{array}{l}\text { Amplified } \\
\text { product }\end{array}$ & Reference \\
\hline \multirow{2}{*}{ Alpha toxin } & $F$ & $\begin{array}{c}\text { GTTGATAGCGCAGGA } \\
\text { CATGTTAAG } \\
\end{array}$ & \multirow{2}{*}{$402 b p$} & \multirow{6}{*}{$\begin{array}{r}\text { YOO et } \\
\text { al., } 1997\end{array}$} \\
\hline & $\mathrm{R}$ & $\begin{array}{c}\text { CATGTAGTCATCTGTT } \\
\text { CCAGCATC }\end{array}$ & & \\
\hline \multirow{2}{*}{ Beta toxin } & $F$ & $\begin{array}{c}\text { ACTATACAGACAGAT } \\
\text { CATTCAACC }\end{array}$ & \multirow{2}{*}{$236 \mathrm{bp}$} & \\
\hline & $\mathrm{R}$ & $\begin{array}{c}\text { TTAGGAGCAGTTAGA } \\
\text { ACTACAGAC }\end{array}$ & & \\
\hline \multirow{2}{*}{ Epsilon toxin } & $F$ & $\begin{array}{c}\text { ACTGCAACTACTACT } \\
\text { CATACTGTG }\end{array}$ & \multirow{2}{*}{541 bp } & \\
\hline & $\mathrm{R}$ & $\begin{array}{c}\text { CTGGTGCCTTAATAG } \\
\text { AAAGACTCC }\end{array}$ & & \\
\hline
\end{tabular}

f. Cycling conditions of the primers during cPCR. g. Agarose gel electrophoreses (Sambrook et al., 1989) with modification.

\section{RESULTS}

All isolates had abundant growth observed in cooked meat broth with significant gas formation, while the meat particles were pinkish and not digested with a sour odor. On $10 \%$ sheep blood agar medium: circular, convex, semi- translucent, smooth colonies with an entire edge were observed. Most of the isolates showed characteristic double zone of hemolysis the inner clear zone due to Beta toxin, and outer zone due to alpha toxin.

Micorscopica1 examination:, all isolates were central or sub terminal oval non bulging endospores. 

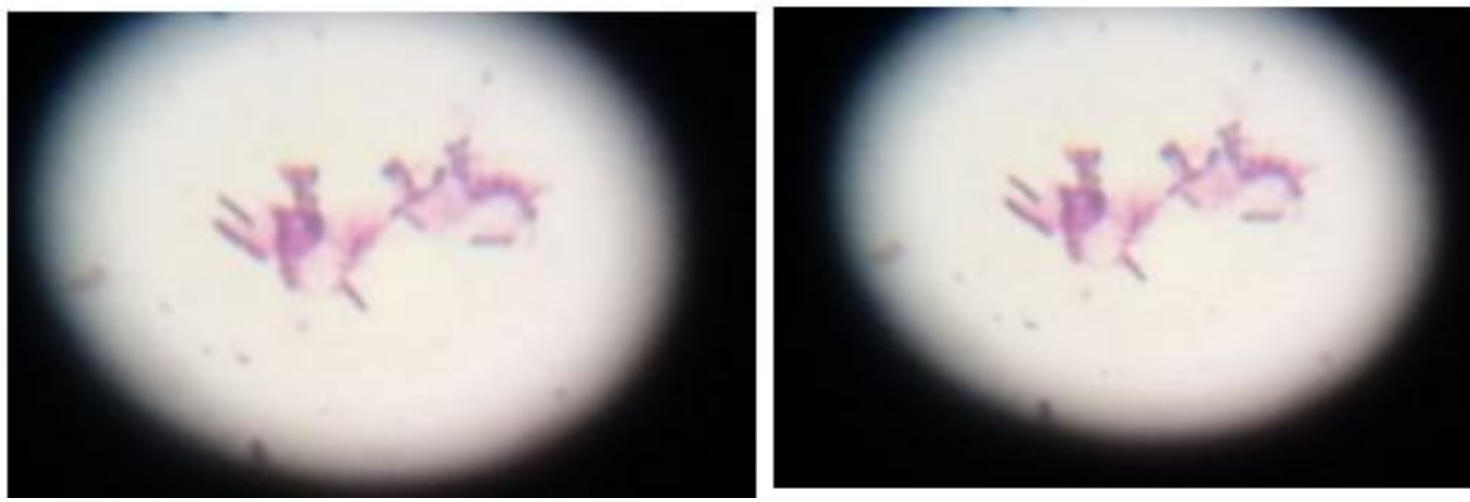

Photo (1): Gram positive bacilli of $C$. perfringens.

Morphologically, all isolates were central or sub terminal oval non bulging endospores

Biochemical characterization of $C$. perfringens indicated that, the isolates were +ve for Catalase, gelatin liquefaction, lactose, sucrose, maltose, mannose, $\mathrm{H}_{2} \mathrm{~S}$ production and Lecithinaseactivity. The isolates gave negative results for Catalase, indole, galactose, manitol and xylose.
The incidences of $C$. perfringens differ significantly $(\mathrm{P}<0.01)$ among different types of the farm. The higher incidences of infection observed in closed farms $(69.20 \%)$ followed by semi closed farms $(22.10 \%)$ and the least infection observed in the open-yard farms (8.70) (Table4).

Table 4: Incidence of $C$. perfringens according to farm system and pasture.

\begin{tabular}{ccc}
\hline Type of farm & Number & Percent \\
\hline Closed & 72 & 69.2 \\
\hline Semi closed & 23 & 22.1 \\
\hline Open - yard & 9 & 8.7 \\
\hline Total & 104 & 100 \\
\hline
\end{tabular}

$\mathrm{Chi}^{2}=8.24 * * \quad * *=$ Significant at $(\mathrm{P}<0.01)$

The significance $(\mathrm{P}<0.01)$ differences of the incidences of $C$. perfringens among sheep and goats of different age (Table 5).The higher incidences observed in newly born kids up to 3 months of age (61.9\%), followed by newly born lamb up to 3 months of age $(55.4 \%)$, followed by its incidences in in lambs from 3 months up to 6 months of age $(28.90$ $\%)$, while, in kids from 3 months up to 6 months of age $(28.60 \%)$. The lower incidences of $C$. perfringens observed in sheep that its age more than 6 months 15.70 and goats $9.5 \%$.

Table 5: Incidence of $C$. perfringens among sheep and goat of different ages.

\begin{tabular}{ccccc}
\hline \multirow{2}{*}{ Age } & \multicolumn{2}{c}{ Sheep } & \multicolumn{2}{c}{ Goat } \\
\cline { 2 - 5 } & Number & Percent & number & Percent \\
\hline Newly born up to 3 months & 46 & 55.4 & 13 & 61.9 \\
\hline From 3 months up to 6 months & 24 & 28.9 & 6 & 28.6 \\
\hline More than 6 months & 13 & 15.7 & 2 & 9.5 \\
\hline Total & 83 & 100 & 21 & 100 \\
\hline
\end{tabular}

$\mathrm{Chi}^{2}=5.23^{* *}$

** = Significant at $(\mathbf{P}<0.01)$

The significance differences of the incidences $C$. perfringens among different types of feeding regime. The higher incidences of $C$. perfingens observed in animals fed concentrates (77 \%), followed by those fed hay and roughe $(15.30 \%)$ and the least incidences observed in mixed feed regimene (table6). 
Table 6: Incidence of $C$.perfringens according to type of feeding.

\begin{tabular}{cccc}
\hline Type of feeding & Number & Percent \\
\hline Concentrates & 80 & 77 \\
\hline Hay and barseem & 16 & 15.3 \\
\hline $\mathbf{C h i}^{2}=\mathbf{5 . 4 7 * *}$ & Mixed & 8 & 7.7 \\
\hline
\end{tabular}

The significance differences of the incidences of $C$. perfringens $(\mathrm{P}<0.01)$ according to the previous vaccination against $C$. perfringens. The higher incidences of $C$. perfringens observed in the nonvaccinated group $(71.20 \%)$, followed by the vaccinated group $(20.10 \%)$ and the least incidences observed in the recently vaccinated group $(8.70 \%)$.
The results recorded that about 21 case of the vaccinated animals were infected with $C$. perfringens, this is due to vaccination failure, there are 16 cases were vaccinated 8 months ago and 4 cases were vaccinated from 3-8 months ago and one case only were vaccinated less than 3 months ago (Table7).

Table 7: Incidence of $C$. perfringens among previous vaccinations against clostridia species.

\begin{tabular}{|c|c|c|}
\hline Previous vaccinations & Number & Percent \\
\hline Non- vaccinated & 74 & 71.2 \\
\hline Recently vaccinated & 9 & 8.7 \\
\hline Vaccinated & 21 & 20.1 \\
\hline Total & 104 & 100 \\
\hline
\end{tabular}

The incidences of $C$. perfringens differ significantly $(\mathrm{P}<0.01)$ in relation to the incidences of the infection of the animals with other types of diseases.
The higher incidences of $C$. perfringens observed in infection of the animals with viral diseases (46.10\%), followed by bacterial diseases $(32.70 \%)$ and the least incidences observed during the infection with mixed infection $(21.10 \%)$ (Table8).

Table 8: Incidence of $C$. perfringens in relation to diseases type.

\begin{tabular}{ccc}
\hline Related disease & Number & Percent \\
\hline Related to viral disease & 48 & 46.1 \\
\hline Related to bacterial disease & 34 & 32.7 \\
\hline Related to mixed infection & 22 & 21.1 \\
\hline Total & 104 & 100 \\
\hline $\mathbf{C h i}^{2}=\mathbf{7 . 2 2} * *$ & $* *$ Significant at $(\mathbf{P}<\mathbf{0 . 0 1})$ &
\end{tabular}

The incidences of $C$. perfringens differ significantly $(\mathrm{P}<0.01)$ among different seasons.The higher incidences of $C$. perfringens observed in winter and autumn seasons $(73 \%)$ and the lower incidences observed in spring and summer seasons (27 \%) (Table9).

Table 9: Incidence of C. perfringens according to seasons.

\begin{tabular}{ccc}
\hline Season & Number & Percent \\
\hline Winter and Autumn & 76 & 73 \\
\hline Spring and Summer & 28 & 27 \\
\hline Total & 104 & 100 \\
\hline Chi2 $=5.33 * *$ & $* *$ Significant at $(\mathbf{P}<0.01)$
\end{tabular}


Molecular characterization of $C$. perfringens (Multiplex PCR)

The positive results showed a higher percentage (50 $\%)$ in Alph toxins, while, the beta and Epsilon toxins not detected in all examined samples. The negative samples observed in alpha toxins (50\%), beta-toxins $(100 \%)$ and Epsilon (100 \%).

Table 10: Multiplex PCR for Molecular characterization of C. perfringens.

\begin{tabular}{|c|c|c|c|c|c|c|}
\hline \multirow[t]{3}{*}{ Sample } & \multicolumn{6}{|c|}{ Results } \\
\hline & \multicolumn{2}{|c|}{ Alpha } & \multicolumn{2}{|c|}{ Beta } & \multicolumn{2}{|c|}{ Epsilon } \\
\hline & No & $\%$ & No & $\%$ & No & $\%$ \\
\hline Positive & 9 & 50 & 0 & 0 & 0 & 0 \\
\hline Negative & 9 & 50 & 18 & 100 & 18 & 100 \\
\hline Total & 18 & 100 & 18 & 100 & 18 & 100 \\
\hline
\end{tabular}

$\mathrm{Chi}^{2}=6.78 * * \quad * *=$ Significant at $(\mathrm{P}<0.01)$

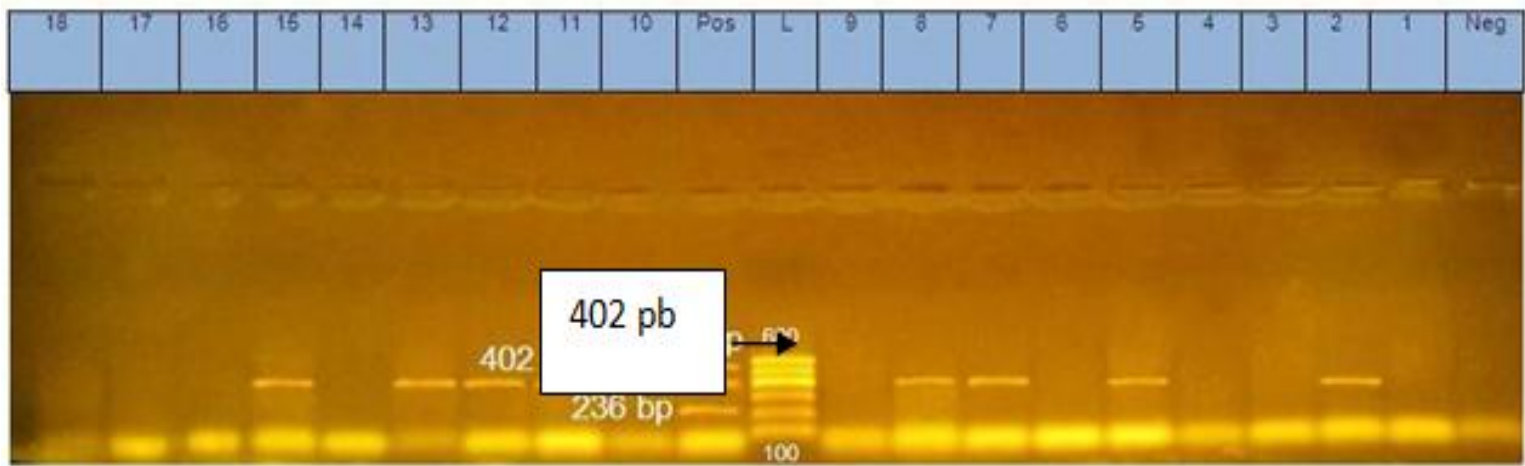

Photo 2: Multiplex PCR, C. perfringenstype"A" (alpha toxin) which gave a characteristic band at 402 bp

Molecular characterization of $C$. perfringens from original tissue sample:

The samples were classified into two groups; the first group was (5 previously examined tissue give positive bacteriology and PCR positive results for C. perfringensstype "A" Alpha Positive and Beta and Epsilon Negative) and the second group was (5 previously examined tissue sample were bacteriologically and PCR negative in previously isolation were submitted for PCR examination from the original tissue:
The results revealed that; the first group givepositive bacteriology and PCR positive results for $\mathrm{C}$. perfringens type "A" Alpha Positive and Beta and Epsilon Negative) and the second group (4) out of (5) examined negative tissue sample were PCR positive for C. perfringens type "A" Alpha Positive and Beta and Epsilon Negative) that conclude the importance of examination of tissue sample with PCR in addition to bacteriological examination. The result show that about $80 \%$ of negative sample bacteriologically revealed positive for PCR that could be turned to failure of isolation due to any reason or low and scanty isolates within examined tissue.

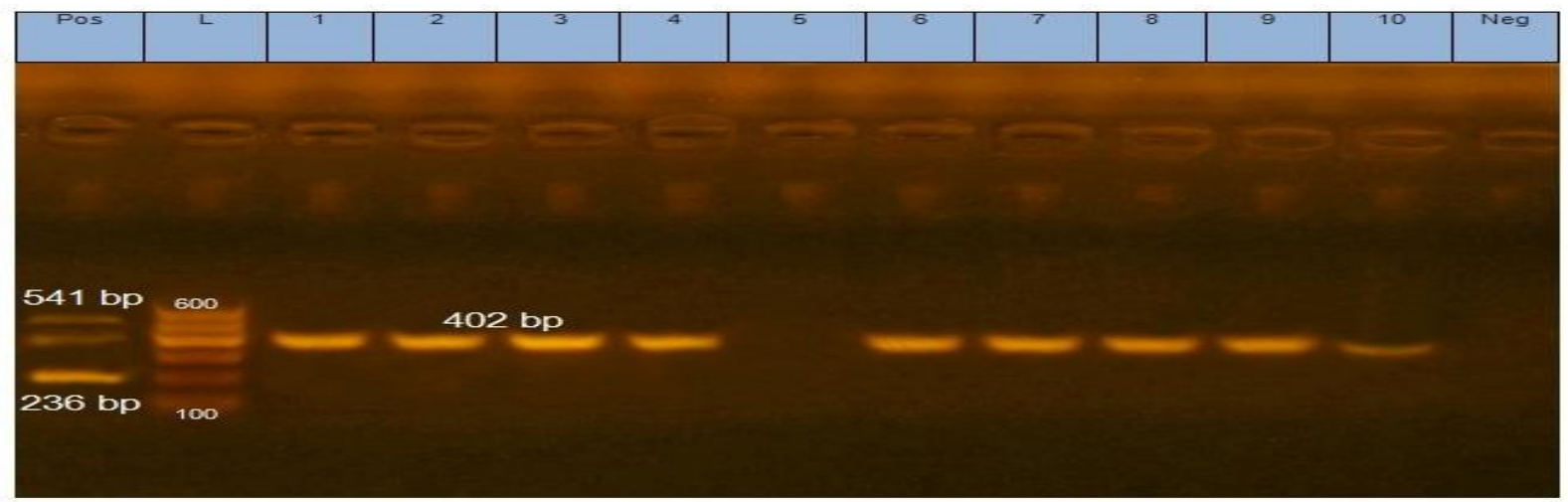

Photo 3: Multiplex PCR, C. perfringens type "A" (alpha toxin) which gave a characteristic band at 402 bp. 


\section{DISCUSSION}

C. perfringens is spore-forming Gram-positive cocci that produce more than 17 toxins (Popoff and Bouvet, 2013). C. perfringens is classified into five main groups $\mathrm{A}$ to $\mathrm{E}$ in relation to the production of four lethal toxins alpha, beta, epsilon and iota toxins (Gurjar et al., 2008). C. perfringens induced enterotoxaemia in sheep and goat represents a major economic obstacle facing developing countries attributable to the high fatality rate, decreased productivity, and increased treatment costs (Greco et al., 2005).

Diarrhea, in appetence and depression were observed in sheep and goats infected with $C$. perfringens followed by collapse and death. Noteworthy, some animals suffered from progressive weakness with the development of nervous signs such as dullness, ataxia, in coordination and convulsive movement of the head with the neck rest laterally on the shoulder.

Regarding the necropsy finding, the data obtained showed that the rumen is full of ingesta, severely congested intestine and bloody fluids in the body cavities.

Our results on colonial character, in cooked meat broth, all isolates had abundant growth observed in cooked meat broth with significant gas formation, while the meat particles were pinkish and not digested with a sour odor. While, on $10 \%$ sheep blood agar medium: circular, convex, semi- translucent, smooth colonies with an entire edge were observed. Most of the isolates showed characteristic double zone of haemolysis the inner clear zone due to Beta toxin, and outer zone due to alpha toxin.

The results of micorscopical examination cleared that, all isolates were Gram positive bacilli, long rod, straight with parallel sides and rounded ends and rarely has central or sub terminal oval non bulging endospores.

Our results agreed with those reported by Elsify et al. (2016) where they reported that, the $C$. perfringens was isolated and characterized based on typical colony morphology on sheep blood agar with a characteristic double zone of hemolysis, while on $C$. perfringens agar medium supplemented with Dcycloserine and egg yolk emulsion, the microorganism appeared as small black colonies surrounded by halo area due to lecithinase activity. Gram-stained smear from the colonies revealed the typical appearance of Gram-positive straight sided rods arranged singly or in pairs.

While, the results of biochemical identification of $C$. perfringens isolates, indicated that the isolates were positive for catalase, gelatin liquefaction, lactose, sucrose, maltose, mannose, $\mathrm{H}_{2} \mathrm{~S}$ production and lecithinase activity, and the isolates gave negative results for catalase, indole, galactose, manitol and xylose. These results agreed with those reported by Nasir et al. (2015) where they observed that, the main biochemical characters of $\mathrm{C}$. perfringens were gas and acid production from glucose, fructose, lactose, sucrose and mannitol was observed. There was a double zone of hemolysis on blood agar. No growth was observed in the aerobic culture.

The incidence of $C$. perfringens according to age; Our results agreed with those reported by Bath et al. (2005) where they observed that, the young animals are most susceptible. Sudden and high mortality rates are concentrated in lambs and kids. Although adult animals are also susceptible to enterotoxemia, they develop immunity due to frequent exposure to these toxins.

The incidence of $C$. perfringens according to farm system and pasture cleared that, closed system is more infection with $C$. perfringens due to Accumulation of bacteria and Humidity. Our results in accordance with Mohiuddin et al. (2016), where they observed that, unsanitary conditions with increasing temperature and humidity facilitate the growth and infection with $C$. perfringens.

Our results on the incidence of $C$. perfringens according to type of feeding cleared that, the higher incidences of $C$. perfingens observed in animals fed concentrates $(77 \%)$, followed by those fed hay rougheand $(15.30 \%)$ and the least incidences observed in mixed feed regime.

Our results on the incidence of $C$. perfringens according to previous vaccinations against clostridia species in agreement with Haenlein (1996) where they found that the prevalence of $C$. perfringenes in healthy sheep and goat and those vaccinated against C. perfringens lower than its incidence in those diseased or non-vaccinated sheep and goats.

While, our results on the incidence of $C$. perfringens related to diseases cleared that, Our results agreed with those of, Habashy et al. (2009) failed to recover any C. perfringens isolates from apparently healthy sheep.

Osman (1993), who successfully isolated $C$. perfringens from $66.5 \%, 17.74 \%$ of samples collected from healthy sheep. While, in case of diseased sheep, the data presented in this study is lower in comparison with that obtained by Abd El-Moez et al. (2014), who showed that, $C$. perfringens was recovered from $77.8 \%$ of diseased sheep with no data regarding apparently healthy and soil. The existence of clostridia spores in soils plus in apparently healthy sheep can produce sporadic diseases episodes that are accountable for massive economic losses in animal 
production through ingestion of the organism and then toxin release (Diego et al., 2012).

While, our results on the incidence of $C$. perfringens according to seasons, cleared that, the infection with Clostridia is very high in winter and autumn due to high humidity and enteritis and changing of pasture.

the Multiplex PCR showed a higher percentage (50 $\%$ ) in Alph toxins, while, the beta and Epsilon toxins not detected in all examined samples. were identified as $C$. perfringens type "A" (alpha toxin) which gave a characteristic band at 402 bp (Yoo et al., 1997). The negative samples observed in alpha toxins (50\%), beta-toxins (100\%) and Epsilon (100\%).

This is consistent with the findings of Gerco et al. (2005), who showed that C.perfringens type A and D are the predominant causes of predominant causes of enterotoxaemia in very young lambs and kids.

Similarly, Abd El-Moez et al. (2014) showed that $C$. perfringens type $\mathrm{A}$ is the predominated type isolated from humans and animals. In contrast, previous studies showed that the main cause of sheep dysentery in UK, South Africa, and Greece was $C$. perfringens type B (Bueschel et al., 2003).

Noteworthy, the finding that no C. perfringens type E strains were identified strongly advocate that $C$. perfringens type $\mathrm{E}$ is rare in lambs and kids (Greco et al., 2005).

C. perfringens in general are associated with several forms of enteric diseases including fatal enterotoxemia in animals. C. perfringens type A is the main causative agent of gas gangrene (myonecrosis) and diarrhea (Hatheway, 1990), while type B and type D are the predominant causes of fatal enterotoxemia in domestic animals (Yamagishi et al., 1997). C. perfringens type $A$ is one of the major toxin producers among clostridia species; however, alpha is representing the main toxin type for this species (Popoff and Bouvet, 2013).

The genetic relationship between the various strains isolated need further investigation. Finally, the high positivity rate to $C$. perfringens type A toxins remarkably counsel counting of this strain in vaccine schedule in order to validate the ample guard to avert the disease in animals.

the Multiplex PCR of $C$. perfringens from original tissue sample show that about $80 \%$ of negative sample bacteriologically revealed positive for PCR that could be turned to failure of isolation due to any reason or low and scanty isolates within examined tissue this agreed with Dean et al. (2011).

Our study concluded that, $C$. perfringens causes severe economic losses in sheep and goats due to causes high mortality and losses among them through enterotoximia that resulted from secretion of Alpha, Beta and Epislon toxins, the higher incidences of $C$. perfringens observed in newly born kids up to 3 months of age, especially in closed farms, in animals fed concentrates, in non-vaccinated group. The higher incidences of $C$. perfringens observed in infection of the animals with viral diseases, followed by bacterial diseases and the least incidences observed during the infection with mixed infection, especially in winter and autumn seasons. The best method for molecular characterization of $C$. perfringens is the Multiplex PCR that characterize C.perfringens type "A" (alpha toxin) which gave a characteristic band at $402 \mathrm{bp}$.

Hence, further studies are requisite to authenticate the molecular association among C.perfringens isolated from soil and apparently healthy sheep in one hand and diseased sheep in the other to trace the source of infection.

\section{REFERENCES}

Abd El-Moez, S.; Dalia, AH.; Dorgham, SM.; Basem, MA.; Eman, AK. and Hedia, RH. (2014): Molecular Characterization and Genetic Diversity among Clostridium perfringens Isolates. Int. J. Curr. Microbiol. Appl. Sci. 3(4): 125-134.

Ashgan M.H.; Abdullah A.A. and Moussa I.M. (2013): Molecular typing of four major toxins of Clostridium perfringens recovered from Egypt. Journal of Food, Agriculture and Environment 11 (1): 151-155.

Bath, G.F.; Van Wyk, J.A. and Pettey, K.P. (2005): Control measures for some important and unusual goat diseases in South Africa. Small Ruminant Research, (60), 127-140.

Bueschel, DM; Jost, BH.; Billington, SJ.; Trinh, HT. and Songer, JG. (2003): Prevalence of cpb2, encoding beta2 toxin, in Clostridium perfringens field isolates: Correlation of genotype with phenotype. Vet. Microbiol. 94:121-129.

Dean, J.B.; Kathryn, M.S.; Jessica, L.C.; Allison, A.A. and Denise, S.O. O'Keefe (2011):False negative results from using common PCRreagents. BMC Res Notes.2011; 4: 457.

Diego, O.O.; Luis C.V.J. and Rodrigo, MS. (2012): Isolation and typing of Clostridium spp.16S rRNA from soil samples obtained in areas with sudden mortality history in Colombia. Adv. Res. J. Microbiol. 1(3): 033-040.

Elsify, A.; Tarabess, R.; Nayel, M.A.; Salama, A.; Allaam, M.; Abd El-Gaber, M.; Hassan, H.; Zaghawa, A. and Elballal, S. (2016): Bacteriological and molecular studies on Clostridium perfringens isolated from sheep in three Egyptian provinces. African Journal of Microbiology Research.10 (20), 725-732, 28. 
Eman, A.K.; Sohad M.D.; Bakry, M.A. and Hakim, A.S. (2013): Molecular Diversity of Alpha Toxin Produced by Clostridium perfringens Strains Causing Avian Necrotic Enteritis .World Appl. Sci. J., 21 (1): 15-20.

Greco, G.; Madio, A.; Buonavoglia, D.; Totaro, M.; Corrente, M.; Martella, V. and Buonavoglia, C. (2005): Clostridium perfringens toxin-types in lambs and kids affected with gastroenteric pathologies in Italy. Vet. J. 170(3): 346-350.

Gurjar, AA.; Hegde, NV.; Love, BC. and Jayarao, BM. (2008): Real-time multiplex PCR assay for rapid detection and toxintyping of Clostridium perfringens toxin producing strains in feces of dairy cattle. Mol. Cell. Probes 22: 90-95.

Haenlein, A.M. (1996): Status and Prospects of the Dairy Goat Industry in the United States. Journal of Animal Science 74: 1173-1181.

Habashy, HF.; Fadel, NG. and El Shorbagy, MM. (2009): Bacteriological and Pathological Studies on the Causes of Mortalities among Sheep in Sharkia-Governorate Farms. Egypt. J. Comp. Path. Clinic. Path. 22(1): 130-146.

Hatheway, CL. (1990): Toxigenic clostridia. Clin. Microbiol. Rev. 3: 66-98.

Jemal, D.; Shifa, M. and Kebede, B. (2016): Review on Pulpy Kidney Disease. J. Vet. Sci Technol. 7: 361

Koneman, E.W.; Allen, S.D.; Dowell, V.R. and Summers, H.W. (1992): "Colour atlas and text book of diagnostic $m$ icrobiology." 4 Ed.J.B. LippinCott, New York, London.

Liu, D. (2011): Molecular Detection of Human Bacterial Pathogens. (Ed.). U.S.A.: Taylor and Francis Group. 367-379 p. 2011

Mohiuddin, M.; Iqbal, Z. and Rahman, S.U. (2016): Prevalence of Clostridium perfringens $\beta 2$ toxin in sheep and goat population in Punjab, Pakistan. Thai J. Vet. Med. 2016. 46(3): 491496.

Moreira, GM1.; Salvarani, FM2.; Da Cunha CE1.; Mendonça, M1.; Moreira, AN3.; Gonçalves, LA4.; Pires, PS4.; Lobato, FC4. and Conceição, FR1. (2016): Immunogenicity of a Trivalent Recombinant Vaccine Against Clostridium perfringens Alpha, Beta, and
Epsilon Toxins in Farm Ruminants. Sci Rep. 2016 Mar 23; 6: 22816.

Nasir, A.A.; Younus, M.; Rashid, A.; Abdul Khaliq, S.; Khan, E.; Shah, S.H. ; Aslam, A.; Ghumman, M.A. and Joiya, M.H. (2015): Clinico-pathological findings of Clostridium perfringens type D enterotoxaemia in goats and its hemolytic activity in different erythrocytes. IJVR, 16 (1): 94-99.

Osman, M. (1993): Enterotoxaemia in sheep and lambs caused by $\mathrm{Cl}$. Perfringes types B, C and D. M.V.SC. Thesis (infectious diseases). Fac. of Vet. Medicine, Assiut University.

Popoff, MR. and Bouvet, P. (2013): Genetic characteristics of toxigenic Clostridia and toxin gene evolution. Toxiconomy, 75: 63-89.

Rodriguez, C. and Daube, G. (2016): Clostridium difficile in Food and Animals: A Comprehensive Review., Adv. Exp. Med. Biol. 2016; 932: 65-92.

Sambrook, J.; Fritsch, E.F. and Maniatis, T. (1989): Purification of closed circular DNA by equilibrium centrifugation in $\mathrm{Cs}-\mathrm{Cl}$ ethidium bromide gradients. Molecular Cloning: a laboratory manual, New York, CSH laboratory.

Smith, L.D.S. and Holdman, L. (1968): "The pathogenic anaerobic bacteria." 1 st Ed., pp. 201-255

Tabaran (2017): Clostridia spread in livestock animals: Situation and initiatives. Int. association of Food Protection.

Vaikosen, E.S. and Muller, W. (2001): Evaluating biochemical tests for isolation and identification of Clostridium perfringens in fecal samples of small ruminants in Nigeria. Bull Anim Health and production in Africa, 49(4): 244-248.

Yamagishi, T.; Sugitani, K.; Tanishima, K. and Nakamura, S. (1997): Polymerase chain reaction test for differentiation of five toxin types of Clostridium perfringens. Microbiol Immunol. 41(4): 295-299.

Yoo, H.S.; Lee, S.U.; Park, K.Y. and Park, Y.H. (1997): Molecular typing and epidemiological survey of prevalence of Clostridium perfringens types by multiplex PCR. J. Clin Microbiol, 35: pp. 228-232.

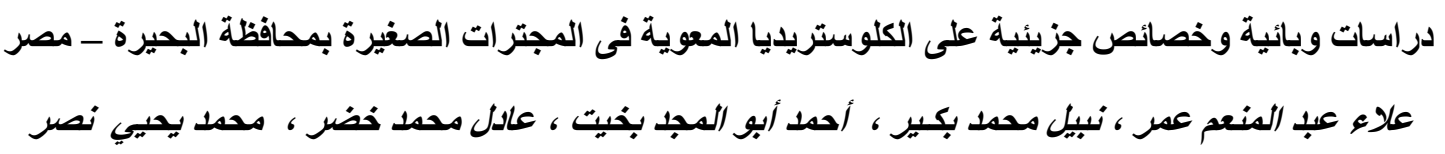

E-mail: ahmadbkheet@yahoo.com

Assiut University web-site: www.aun.edu.eg

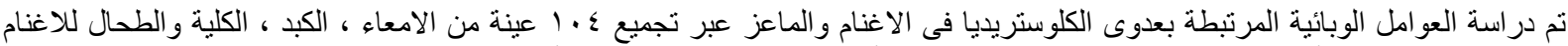

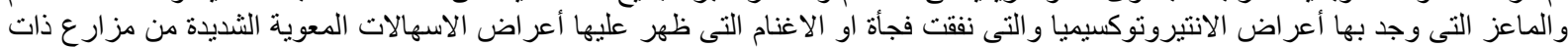

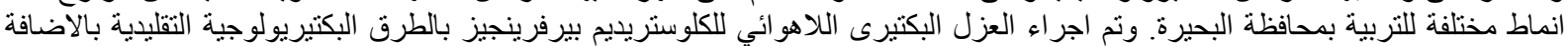

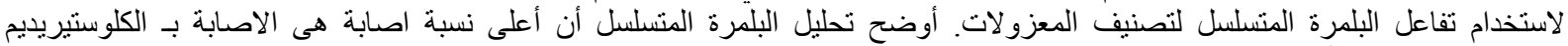

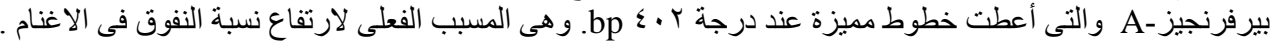
الكلمات الدالة : الكولستريديم برفرنجينز ، انتيروتوكسيميا ، الوبائية تفاعل البلمرة المتسلسل ملتى بلكس اغنام ، ماعز 